\title{
A COPA DO MUNDO É REALMENTE NOSSA?
}

\author{
| POR PEDRO TRENGROUSE
}

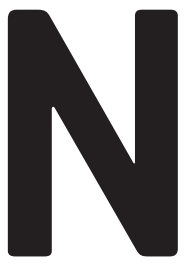

o primeiro semestre de 2010, a Federação Internacional de Futebol (FIFA) já tinha conseguido levantar mais dinheiro para a Copa do Mundo que acontecerá no Brasil em 2014 do que para o mesmo campeonato ocorrido naquele ano na África. Só em 2011, a FIFA arrecadou cerca de R\$ 2 bilhões com o mundial no Brasil, e a previsão é de que consiga mais de R\$ 8 bilhões no ciclo 2010/2014.

As principais fontes de receita para que a Federação consiga tanto dinheiro com o evento esportivo são os direitos de transmissão, vendidos para TVs do mundo inteiro, e as cotas de patrocínio compradas por grandes empresas multinacionais, como AmBev, Coca-Cola, Adidas, Sony, Hyundai, Visa, Itaú, McDonalds, Seara, Oi, Johnson \& Johnson, etc.

Estima-se ainda que as TVs e os patrocinadores invistam valor semelhante em publicidade, promoções e eventos particulares para promover suas propriedades durante o campeonato.

Apesar de tudo isso, quem mais coloca dinheiro no mundial de 2014 é o Governo. O investimento público passa de R\$ 25 bilhões. Só em estádios, serão gastos mais de $\mathrm{R} \$ 6$ bilhões.

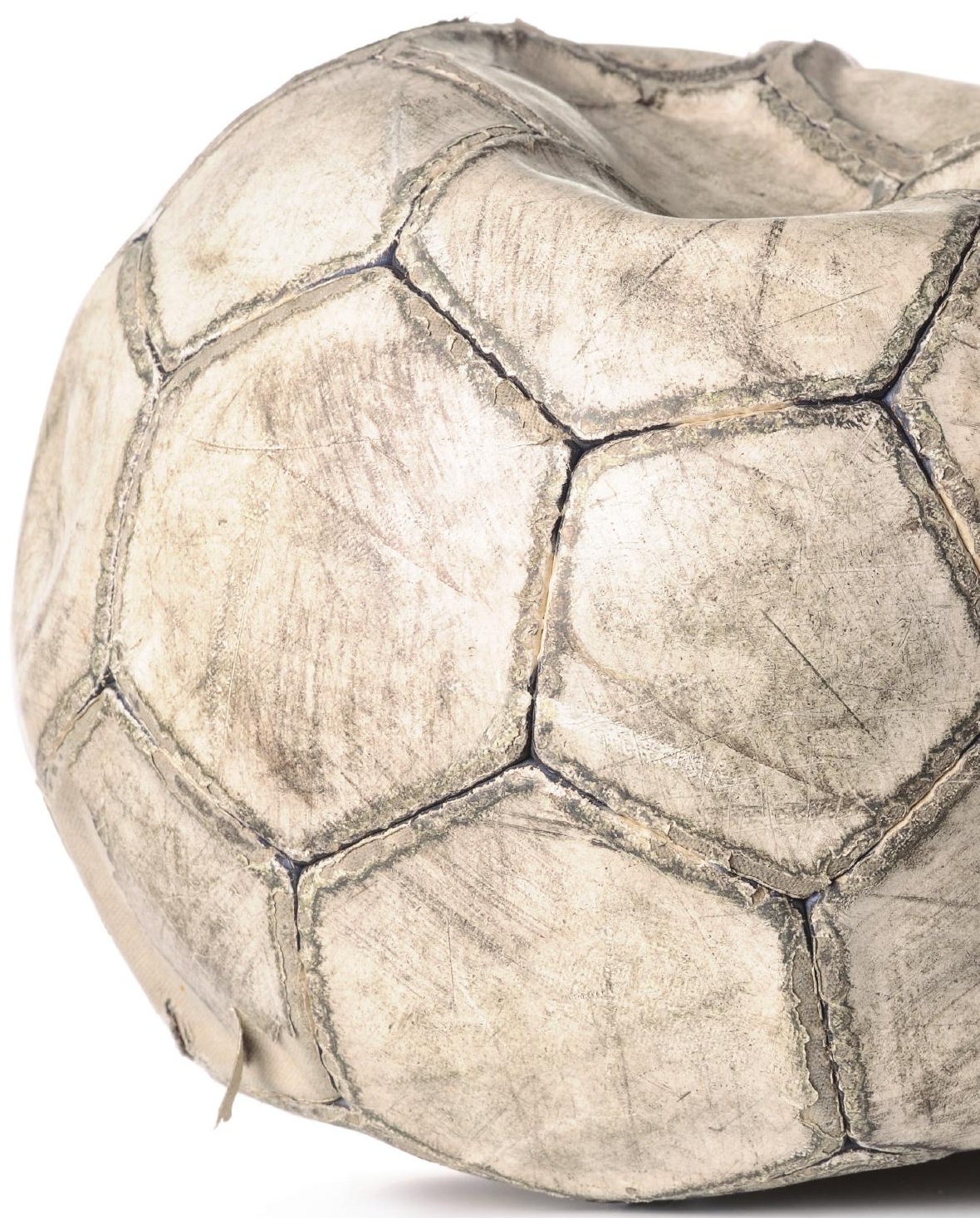


